\title{
Adiponectin, Leptin, IGF-1, and Tumor Necrosis Factor Alpha As Potential Serum Biomarkers for Non-Invasive Diagnosis of Colorectal Adenoma in African Americans
}

\begin{abstract}
Hassan Ashktorab ${ }^{1 *}$, Akbar Soleimani ${ }^{2}$, Alexandra Nichols ${ }^{3}$, Komal Sodhi ${ }^{3}$, Adeyinka O. Laiyemo ${ }^{1}$, Gail Nunlee-Bland ${ }^{1,4}$, Seyed Mehdi Nouraie ${ }^{5}$ and Hassan Brim ${ }^{6}$

${ }^{1}$ Department of Medicine, Cancer Center, College of Medicine, Washington, DC, United States, ${ }^{2}$ Islamic Azad University, Kashmar, Iran, ${ }^{3}$ Department of Surgery and Pharmacology, Translational Research, Marshall University Joan Edwards School of Medicine, Huntington, WW. United States, ${ }^{4}$ Endocrinology Division, College of Medicine, Howard University, Washington, DC, United States, ${ }^{5}$ University of Pittsburg, Medical Center, Pittsburg, PA, United States, ${ }^{6}$ Pathology Department, College of Medicine, Washington, DC, United States
\end{abstract}

OPEN ACCESS

Edited by: Michele Caraglia, Università degli Studi della Campania Luigi Vanvitelli, Caserta, Italy

Reviewed by: Alessio Paone,

Sapienza Università di Roma, Italy Gabriella Misso, Università degli Studi della Campania Luigi Vanvitelli, Naples, Italy

${ }^{*}$ Correspondence: Hassan Ashktorab hashktorab@howard.edu

Specialty section: This article was submitted to

Cancer Endocrinology, a section of the journal Frontiers in Endocrinology

Received: 02 November 2017 Accepted: 19 February 2018

Published: 12 March 2018

Citation: Ashktorab H, Soleimani A, Nichols A, Sodhi K, Laiyemo AO, NunleeBland G, Nouraie SM and Brim H (2018) Adiponectin, Leptin, IGF-1, and Tumor Necrosis Factor Alpha As

Potential Serum Biomarkers for Non-Invasive Diagnosis of Colorectal Adenoma in African Americans.

Front. Endocrinol. 9:77. doi: 10.3389/fendo.2018.00077
The potential role of adiponectin, leptin, IGF-1, and tumor necrosis factor alpha (TNF- $\alpha$ ) as biomarkers in colorectal adenoma is not clear. Therefore, we aimed to investigate the blood serum levels of these biomarkers in colorectal adenoma. The case-control study consisted of serum from 180 African American patients with colon adenoma (cases) and 198 healthy African Americans (controls) at Howard University Hospital. We used ELISA for adiponectin, leptin, IGF-1, and TNF- $\alpha$ detection and quantification. Statistical analysis was performed by $t$-test and multivariate logistic regression. The respective differences in median leptin, adiponectin, IGF-1, and TNF- $\alpha$ levels between control and case groups (13.9 vs. 16.4 ), (11.3 vs. 46.0$),(4.5$ vs. 12.9$)$, and (71.4 vs. 130.8) were statistically significant $(P<0.05)$. In a multivariate model, the odds ratio for adiponectin, TNF- $\alpha$, and IGF-1 were $2.0(95 \% \mathrm{Cl}=1.6-2.5 ; P<0.001), 1.5(95 \% \mathrm{Cl}=1.5(1.1-2.0) ; P=0.004)$, and $1.6(95 \% \mathrm{Cl}=1.3-2.0 ; P<0.001)$, respectively. There was a positive correlation between serum adiponectin and IGF-1 concentrations with age $(r=0.17, P<0.001$ and $r=0.13, P=0.009$ ), TNF- $\alpha$, IGF-1, and leptin concentration with body mass index (BMI) $(r=0.44, P<0.001 ; r=0.11, P=0.03$; and $r=0.48, P<0.001)$, respectively. Also, there was a negative correlation between adiponectin and leptin concentrations with BMI $(r=-0.40, P<0.001)$, respectively. These data support the hypothesis that adiponectin, IGF-1, and TNF- $\alpha$ high levels correlate with higher risk of colon adenoma and can thus be used for colorectal adenomas risk assessment.

Keywords: adiponectin, leptin, IGF-1, tumor necrosis factor alpha, biomarkers, colorectal adenomas, African Americans

\section{INTRODUCTION}

Colorectal cancer (CRC) is the third most commonly identified cancer in the United States for both genders (1). CRC in African Americans has a higher incidence and mortality in comparison to Whites. The mean age of CRC development in African Americans is lower than in Whites and Asian Pacific Islanders $(2,3)$. There is also evidence for a more proximal colonic distribution of lesions in African Americans (2). Epidemiologic studies have documented obesity as a risk factor for colorectal neoplastic transformation $(4,5)$. An association between body/abdominal 
fat and CRC was established (6). Fat tissue is progressively viewed not only as an energy storage site but also as an active endocrine tissue that produces and secrets proteins that act as hormones (7-9). So far, 20 adipohormones have been described. According to their physiological role, they have been divided into two groups: insulin resistance inducting factors such as resistin, tumor necrosis factor alpha (TNF- $\alpha$ ), and interleukin 6 (IL-6) and insulin-sensitizing factors such as leptin, adiponectin, and visfatin $(10,11)$. Adipocytes' secreted proteins might be the possible link between obesity and colon cancer. Indeed, adiponectin and leptin play an important role in energy homeostasis, glucose and lipid metabolism, immunity, bone formation, and regulation of body weight (12-14). These proteins can directly alter cancer risk by activating signal transduction pathways involved in carcinogenesis. They can also do so indirectly by acting on insulin sensitivity and the inflammatory response $(15,16)$.

Adiponectin is a unique adipokine, with two isoforms, secreted from abdominal fat tissue. It has antidiabetic, antiatherosclerotic, and anti-inflammatory effects (17) and directly modulates several intracellular signaling pathways involved in colorectal carcinogenesis (18-22).

Leptin, a 167 amino acid peptide, plays a vital role in the hypothalamus in relation to mammalian feeding behavior and energy expenditure and is a useful serum biomarker that reflects total body fat over a wide range of body mass indexes (BMIs) (23-25). Leptin was shown to promote colonic cell growth in in vitro and in human studies independently of insulin (26-28).

IGF-1, a growth and proliferation promotor, has also inhibitory effects on cell death and was reported as a major player in many disease processes including colon neoplastic transformation $(29,30)$.

One of the key chemical mediators implicated in inflammationassociated cancers is TNF- $\alpha$ which leads to activation of the NF- $\kappa \mathrm{B}$ and AP-1 transcription factor complexes. TNF- $\alpha$ is frequently detected in biopsies from human cancer, produced by either epithelial tumor or stromal cells (31). TNF- $\alpha$ production by tumors has been associated with a poor prognosis, loss of hormone responsiveness, and cachexia/asthenia $(32,33)$.

The role of metabolic markers such as leptin, adiponectin, IGF-1, and TNF- $\alpha$ in the progression of diseases is becoming more significant. Indeed several studies have previously reported the correlation of such markers, individually, with colorectal neoplasia in different populations (34-38). However, none of these studies have addressed the association of these metabolic markers combined with the risk of colorectal neoplasia in a African Americans a population with higher prevalence of obesity, diabetes and colon cancer than other ethnic groups in the US population. Therefore, in the present study, we assessed the serum levels of these metabolites in an African American case-control study, where cases correspond to adenoma stages.

\section{MATERIALS AND METHODS}

\section{Study Population}

Study participants were recruited from patients who underwent colonoscopy at Howard University Hospital either for screening or for diagnostic purposes between 2009 and 2015. The study was approved by the Howard University Institutional Review Board and consent forms were obtained from all participants. The total number of patients enrolled in this study was 378, including 180 cases (adenoma) and 198 controls (healthy African American controls with no colorectal lesions). Information about demographic characteristics, age, sex, weight, height, BMI, medical history, smoking, and other lifestyle exposures was collected from medical records. Within the control population, $14 \%$ presented with symptoms while only $10 \%$ of cases were symptomatic.

\section{Adiponectin, Leptin, TNF- $\alpha$, and IGF-1 Analyses}

The blood specimens were obtained from African American patients on the day of colonoscopy. Blood samples were centrifuged for $15 \mathrm{~min}$ at a speed of $3,500 \mathrm{~g}$ at $4^{\circ} \mathrm{C}$ then sera were separated and stored at $-80^{\circ} \mathrm{C}$. Serum concentrations of adiponectin (pg/ml), leptin (pg/ml), TNF- $\alpha$ (pg/ml), and IGF-1 (ng/ml), were quantified using commercially available ultrasensitive ELISA kits according to the manufacturer's recommendations (Abcam, Cambridge, MA, USA).

\section{Statistical Analysis}

Distribution of continuous data was presented by median (interquartile range) while categorical data was presented by tables of frequencies. Serum biomarkers were transformed to best normal distribution if required and were tested by $t$-test between cases and controls. Chi-square test was used for categorical data. A stepwise backward logistic regression analysis was applied to assess the significant relationship between biomarkers with risk of adenoma. Then we added important confounders in this model to assess the significant predictors of adenoma. We also used receiver operating characteristics curve (ROC) for each biomarker and test of different ROC to assess the diagnostic ability of different markers. All analyses were performed in STATA 14.0 (StataCorp., College Station, TX, USA). Two-tailed $P<0.05$ were considered statistically significant.

\section{RESULTS}

\section{Characteristics of the Case and Control Groups}

There were 111 (56\%) and 91 (51\%) females among controls and cases, respectively. The median ages and BMIs were 58 years and 28.5 for controls and 60 years and 28.4 for cases. There was no significant difference in age and gender between the two groups. The prevalence of overweight and obese subjects was significantly higher in the adenoma group $(P=0.026)$. Smoking was also higher in the case group (adenoma) [59 (33\%)] vs. control group [36 (18\%)], $(P=0.001)$ (Table 1). There were more diverticular lesions among cases than controls $[109(62 \%)$ vs. $96(52 \%)]$ and hypertension [88 (49\%) vs. $79(40 \%)]$, respectively. The cases in this study had adenoma, primarily of the tubular type. No statistically significant differences were noted for all other parameters 
TABLE 1 | Distribution of demographic, clinical, and inflammatory markers in case and controls.

\begin{tabular}{|c|c|c|c|c|c|}
\hline & \multicolumn{2}{|c|}{ Controls } & \multicolumn{2}{|c|}{ Cases } & \multirow[t]{2}{*}{$P$-value ${ }^{a}$} \\
\hline & $N$ & Results & $N$ & Results & \\
\hline Age, median (IQR) & 198 & $58(53-65)$ & 180 & $60(53-66)$ & 0.2 \\
\hline Female gender & 198 & $111(56 \%)$ & 180 & $91(51 \%)$ & 0.3 \\
\hline Body Mass Index, median (IQR) & 198 & $28.5(24.6-33.7)$ & 180 & $28.4(25.6-33.4)$ & 0.8 \\
\hline Overweight and obese & 198 & $140(71 \%)$ & 180 & $145(81 \%)$ & 0.026 \\
\hline Smoking & 198 & $36(18 \%)$ & 180 & 59 (33\%) & 0.001 \\
\hline Alcohol & 198 & $81(41 \%)$ & 179 & $78(44 \%)$ & 0.6 \\
\hline Exercise time per week, median (IQR) & 198 & $3(0-4)$ & 180 & $3(0-4)$ & $>0.9$ \\
\hline \multicolumn{6}{|l|}{ Location } \\
\hline Ascending & - & - & 180 & $154(86 \%)$ & - \\
\hline Transverse & - & - & 180 & $8(4 \%)$ & - \\
\hline Descending & - & - & 180 & 71 (39\%) & - \\
\hline Rectosigmoid & - & - & 180 & $91(51 \%)$ & - \\
\hline History of colon disease & 198 & $4(2 \%)$ & 180 & 1 (0.6\%) & 0.2 \\
\hline History of colon polyp & 198 & $29(15 \%)$ & 180 & $29(16 \%)$ & 0.7 \\
\hline Family history of colon cancer & 198 & $26(13 \%)$ & 180 & $32(18 \%)$ & 0.2 \\
\hline Reason for colonoscopy & 196 & & 180 & & 0.3 \\
\hline Screening & & $117(60 \%)$ & & 119 (66\%) & \\
\hline Follow-up & & $52(26 \%)$ & & 44 (24\%) & \\
\hline Symptoms & & 27 (14\%) & & 17 (10\%) & \\
\hline Diverticular disease & 184 & $96(52 \%)$ & 177 & 109 (62\%) & 0.07 \\
\hline Dyslipidemia & 198 & 38 (19\%) & 179 & $28(16 \%)$ & 0.4 \\
\hline Dyslipidemia medication & 198 & $51(26 \%)$ & 180 & $44(24 \%)$ & 0.8 \\
\hline Diabetes & 198 & $33(17 \%)$ & 179 & 32 (18\%) & 0.8 \\
\hline Diabetes medication & 198 & 39 (20\%) & 179 & $37(21 \%)$ & 0.8 \\
\hline Hypertension & 198 & 79 (40\%) & 179 & 88 (49\%) & 0.07 \\
\hline Hypertension medication & 198 & $108(55 \%)$ & 179 & 109 (61\%) & 0.2 \\
\hline Aspirin & 198 & 58 (29\%) & 180 & 60 (33\%) & 0.4 \\
\hline
\end{tabular}

${ }^{a}$ From t-test for continuous variables and chi-2 for categorical variables.

(Table 1). All controls' sera were drawn from African Americans undergoing colonoscopy under the same condition as cases.

\section{Metabolic Biomarkers in Adenoma Cases and Lesion-Free Controls}

Serum concentrations of adiponectin ( $\mathrm{pg} / \mathrm{ml})$, IGF-1 ( $\mathrm{ng} / \mathrm{ml})$, TNF- $\alpha(\mathrm{pg} / \mathrm{ml})$, and leptin $(\mathrm{pg} / \mathrm{ml})$ were significantly higher in adenoma group (Table 2). The respective differences in median adiponectin, IGF-1, and TNF- $\alpha$ levels between control and case groups [(11.3 vs. 46.0$)$, (4.5 vs. 12.9$)$, and (71.4 vs. 130.8$)$, respectively] were statistically significant $(P<0.001)$. Median serum leptin concentration in adenoma cases was 16.4 vs. 13.9 in controls $(P=0.048)$.

\section{Correlation between Age, BMI and Analyzed Biomarkers}

In controls, there was a positive correlation between serum adiponectin and IGF- 1 concentrations and patients' age. In both cases and control, there was statistically significant correlation between adiponectin, TNF- $\alpha$, and leptin concentrations and BMI. Also, there was a positive correlation between IGF-1 concentration and BMI in cases $(r=0.25, P<0.001)$ (Table 3).

In a multivariate logistic regression analysis using the biomarkers, colon adenoma occurrence increased with increasing concentrations of adiponectin with an odds ratio (OR) of 2.0 (95\% CI $=1.6-2.5 ; P<0.001)$. Interestingly, this effect was limited to adiponectin of 100 . The corresponding ORs for TNF- $\alpha$
TABLE 2 | Serum adiponectin, IGF-1, tumor necrosis factor alpha (TNF- $\alpha$ ), and leptin levels in cases and controls.

\begin{tabular}{|c|c|c|c|c|c|}
\hline \multirow[t]{2}{*}{ Biomarkers } & \multicolumn{2}{|r|}{ Controls } & \multicolumn{2}{|r|}{ Cases } & \multirow[b]{2}{*}{$P$-value ${ }^{a}$} \\
\hline & $N$ & Value & $N$ & Value & \\
\hline $\begin{array}{l}\text { Adiponectin } \\
(\mathrm{pg} / \mathrm{ml}) \text {, } \\
\text { median (IQR) }\end{array}$ & 198 & 11.3 (1.5-26.9) & 180 & $46.0(21.4-115.2)$ & $<0.001$ \\
\hline $\begin{array}{l}\text { IGF-1 (ng/ml), } \\
\text { median (IQR) }\end{array}$ & 198 & $4.5(0.2-12.6)$ & 180 & $12.9(7.6-20.6)$ & $<0.001$ \\
\hline $\begin{array}{l}\text { TNF- } \alpha(p g / m l) \\
\text { median (IQR) }\end{array}$ & 198 & $71.4(7.3-158.0)$ & 180 & $130.8(56.0-228.7)$ & $<0.001$ \\
\hline $\begin{array}{l}\text { Leptin (pg/ml), } \\
\text { median (IQR) }\end{array}$ & 198 & $13.9(4.5-36.5)$ & 180 & $16.4(3.1-28.7)$ & 0.048 \\
\hline
\end{tabular}

a From t-test.

and IGF-1 were $1.5(95 \% \mathrm{CI}=1.5-2.0 ; P=0.004)$ and $1.6(95 \%$ $\mathrm{CI}=1.3-2.0 ; P<0.001)$ (Table 4). The OR for leptin was not significant in this analysis $(P=0.8)$. In this model, BMI could be replaced for TNF with OR: $1.06(95 \% \mathrm{CI}=1.5(1.1-2.0))$ for each unit increase. Smoking was also a significant predictor of higher risk of adenoma with an OR: $2.5(95 \% \mathrm{CI}=1.4-4.5)$.

\section{Area under the Curve (AUC)}

For each biomarker, the AUC with 95\% confidence intervals was calculated to assess its usefulness as a sensitive and specific 
TABLE 3 | Correlation between age, Body Mass Index (BMI), and serum biomarkers, values are Pearson correlation ( $P$-value).

\begin{tabular}{|c|c|c|c|c|c|c|}
\hline & \multicolumn{3}{|c|}{ Age } & \multicolumn{3}{|c|}{ BMI } \\
\hline & All & Cases & Control & All & Cases & Control \\
\hline Adiponectina & $0.17(<0.001)$ & $0.13(0.07)$ & $0.19(0.007)$ & $-0.40(<0.001)$ & $-0.44(<0.001)$ & $-0.41(<0.001)$ \\
\hline $\mathrm{TNF}^{\mathrm{a}}$ & $0.06(0.3)$ & $-0.01(0.9)$ & $0.07(0.3)$ & $0.44(<0.001)$ & $0.70(<0.001)$ & $0.32(<0.001)$ \\
\hline IGF-1a & 0.13 (0.009) & $0.06(0.4)$ & $0.16(0.03)$ & $0.11(0.030)$ & $0.25(<0.001)$ & $0.05(0.4)$ \\
\hline Leptin & $-0.01(0.9)$ & $-0.07(0.4)$ & $0.04(0.6)$ & $0.48(<0.001)$ & $0.60(<0.001)$ & $0.37(<0.001)$ \\
\hline
\end{tabular}

${ }^{a}$ Natural log.

TABLE 4 | Multivariate analysis of serum biomarkers in cases and controls. ${ }^{\text {a }}$

\begin{tabular}{lcr}
\hline Biomarkers & Odds ratios (95\% confidence intervals) & $\boldsymbol{P}$-value \\
\hline Adiponectin (natural log) & & $<0.001$ \\
TNF (natural log) & $2.0(1.6-2.5)$ & 0.004 \\
IGF (natural log) & $1.5(1.1-2.0)$ & $<0.001$
\end{tabular}

${ }^{a}$ Area under the curve $(95 \% \mathrm{Cl}$ ) for the model $=0.80$ (0.75-0.84).

${ }^{b}$ The effect of adiponectin was significant up to adiponectin of $100(O R=3.1$ for each

natural log). Then this effect was not significant $(O R=0.7, P=0.3)$.

biomarker for colorectal adenoma diagnosis. The AUC for adiponectin, IGF-1, and TNF- $\alpha$ were $0.75(0.70-0.80), 0.71$ (0.66-0.77), and $0.64(0.59-0.70)$. The AUC was lowest for leptin 0.59 (0.53-0.65) (Figure 1).

We then used the Youden index to select the optimum cut point for each serum marker to discriminate cases from controls. The best sensitivity was detected for an IGF $>6.84$ and the best specificity and positive likelihood ratio were detected for an adiponectin $>23.90$ (Table 5 ).

\section{DISCUSSION}

Colon adenoma is a precursor for colon cancer, if not detected early. Metabolic biomarkers are important indicators for prediction of colon disease. The present study explored serum adiponectin, leptin, IGF-1, and TNF- $\alpha$ association with colon adenoma. Our results showed significant differences in levels of serum adiponectin, IGF- 1 , and TNF- $\alpha$ in case (adenoma) and control groups (healthy normal). The OR for adiponectin, TNF- $\alpha$, and IGF- 1 were $2.0,1.5$, and 1.6, respectively. There was a positive correlation between serum adiponectin and IGF-1 concentrations with age, TNF- $\alpha$, IGF-1, and leptin concentrations with BMI. However, there was a negative correlation between adiponectin concentration and BMI. Obesity has been reported to be a risk factor of colorectal adenoma and is known to be associated with $\operatorname{CRC}(39,40)$. Obesity also occurs more frequently in African Americans than European Americans (41). Keimling et al. (42) reported increased colon cancer risks with higher BMI and waist circumference in men, but in women these anthropometric variables were unrelated to colon cancer. Obesity-related colorectal carcinogenesis is widely correlated with insulin resistance, which links colorectal adenoma to visceral obesity, physical inactivity and metabolic syndrome (43). As such, subtle non-invasive methods of assessing obesity-related molecules are of relevance in African Americans who suffer from obesity and CRC in a

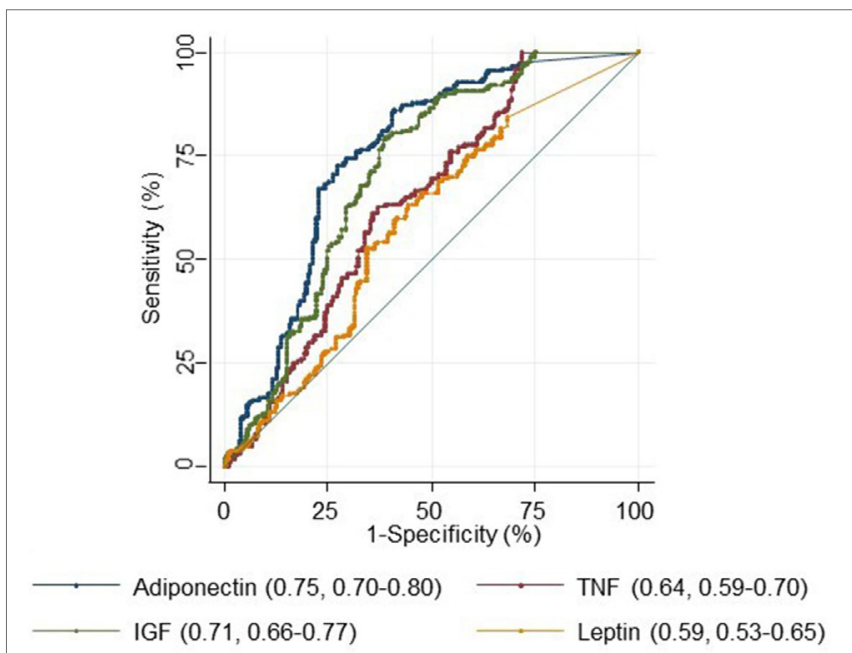

FIGURE 1 | Receiver operating characteristics curve for adiponectin, tumor necrosis factor alpha (TNF- $\alpha$ ), IGF-1, and leptin.

TABLE 5 | Discriminative power of serum biomarkers based on optimum cut point.

\begin{tabular}{lccc}
\hline Biomarkers & Sensitivity & Specificity & Likelihood ratio+ \\
\hline Adiponectin $>$ 23.90 & 73 & 73 & 2.67 \\
IGF-1 $>6.84$ & 79 & 61 & 2.04 \\
TNF- $\alpha>106.11$ & 63 & 63 & 1.70 \\
Leptin $>9.62$ & 63 & 56 & 1.43 \\
\hline
\end{tabular}

disproportionate manner. In the present study, we measured four serum biomarkers in patients with colon adenomas and compared their values to age- and gender-matched African American controls.

Adipocytokines have been the focus of intense study as novel risk biomarkers not only of metabolic syndrome but also of cancers (44). An inverse correlation between adiponectin level and colorectal adenoma has also been reported by several studies $(20,45,46)$ which is not in agreement with our results. In addition, adiponectin levels were not associated with risk of colon adenoma in a Japanese case-control study (47) or in nested case-control studies of Norwegian and Swedish CRC patients $(48,49)$. In other case-control studies, the correlation between adiponectin level and CRC remains debatable $(44,50)$. However, we had no information regarding body weight changes in the patients and controls before the sampling, and consequently it 
was not possible to determine whether or not adiponectin levels' increase was a result of obesity and adenoma outcome or a prior event. Our result is in line with Chong et al. and Inamura et al. who reported that high adiponectin plasma levels in colon cancer patients associate with poor prognosis and KRAS wild type tumors $(51,52)$. This study (51) showed among CRC patients, prediagnostic plasma adiponectin is associated with an increased risk of CRC-specific and overall mortality and is more apparent in patients with metastatic disease. They showed that adiponectin may be a marker for cancers that develop through specific pathways that may be associated with colorectal progression and poor prognosis.

Under high level of adiposity, macrophages are known to store in white adipose tissue, possibly in response to increasing levels of chemotactic signals. This leads to the secretion of a range of proinflammatory peptides from adipocytes and macrophages. In contrast to lean individuals, obese subjects' adipose tissue expresses higher quantities of proinflammatory molecules such as TNF- $\alpha$, IL- 6 , inducible nitric oxide synthase, and monocyte chemotactic protein-1 (53). Our result is consistent with the above studies reflecting an increase of leptin and TNF- $\alpha$ that is associated with BMI. Adiponectin suppresses the secretion of inflammatory cytokines such as TNF- $\alpha$ and induces the secretion of anti-inflammatory cytokines such as IL-10 (54). It has been reported to prevent tumor growth by suppressing angiogenesis in vitro and in vivo (55). Leptin is expected to be increased in obese patients such as our case population. In such patients, a decreased sensitivity to leptin occurs, resulting in failure to detect satiety, despite high energy stores. There is accumulating evidence that leptin signaling might be involved in colon cancer (56). Leptin activities are mediated through the transmembrane leptin receptor (ObR) (57), of which at least four isoforms of ObR with different $\mathrm{COOH}$-terminal cytoplasmic domains have been described (58). The presence of ObRs and ObRl mRNA has been demonstrated in colon cancer cell lines, human colon tumors, polyps, and adjacent mucosa (56). It is observed that higher levels of leptin were linked with about a double increase in risk of CRC in men (59) which is consistent with our results. On the other hand, other studies show that no statistically significant differences were noted between patients with colorectal adenoma and normal control subjects $(60,61)$. In contrast, another study noted that serum leptin levels in patients with colon cancer were significantly decreased (7) despite lack of weight loss and BMI measurements when compared to control subjects.

Through a meta-analysis on IGF-1 and colorectal adenoma, Yoon et al. (62) reported that circulating levels of IGF-1, IGFBP1, and IGF-1/IGFBP-3 ratio were not associated with a risk of occurrence of colorectal adenoma but IGF-1 was associated with increased risk of occurrence of advanced colorectal adenoma. Our serum IGF-1 result is consistent with several studies $(63,64)$ that showed that higher IGF-1 level was significantly associated with increased risk of colorectal adenoma. However, most studies included in the meta-analysis (65) showed no such associations $(63,64)$. Kang et al. (66) did not observe any significant relationships between IGF-I and adenoma recurrence while another study resulted in IGF-I levels inverse association with colorectal adenoma recurrence and this inverse association was stronger for advanced adenoma recurrence than for non-advanced recurrence (67). These inconsistencies may be a result of different patient population, environmental impact, and methodology.

Recent evidence indicates that TNF- $\alpha$ serum level may be elevated in patients with colorectal adenoma that is consistent with our results $(26,68)$. However, our study is not in agreement with Vaughn et al. (69) that found no statistically significant associations between TNF- $\alpha$ and colon adenoma. Based on their investigation which focused on the associations between these cytokines and CRC $(26,70)$, it is possible these cytokines impact the progression of CRC rather than the initiation.

We established a positive correlation between serum adiponectin and IGF-1 concentrations and patients' age. A study by Ryan et al. did not establish any age-related increase of adiponectin (71) with different BMI. However, this study did not include any colon adenoma. As a regulator of cell growth, IGF-1 was supposed to be equally, if not less, prevalent in the cases compared to control group. As such, its cell growth promoting features and increased serological quantity in cases is to be understood in the context of colonic neoplasia, rather than age itself.

There was also a positive correlation between TNF- $\alpha$, IGF-1, and leptin concentrations and BMI. These findings are consistent with the status of these three markers in obese and overweight individuals. There was however a negative correlation between adiponectin concentration and BMI $(r=-0.40$, $P \leq 0.001$ and Table 3). This finding is also expected as adiponectin is known to be inversely related to obesity and as such its increased concentration in our cases' sera is to be assigned to colorectal neoplasia-associated processes. Indeed, in multivariate logistic regression analysis, colon adenoma risk increased with increasing concentrations of adiponectin with an OR of 2.0 (95\% CI $=1.6-2.5 ; P \leq 0.001)$. The corresponding ORs for TNF- $\alpha$ and IGF-1 were 1.5 (95\% CI $=1.5-2.0$; $P=0.004)$ and $1.6(95 \% \mathrm{CI}=1.3-2.0 ; P \leq 0.001)$ (Table 4). The OR for leptin was not significant in this model. Similarly, the AUC with 95\% confidence intervals to assess the sensitivity and specificity of the biomarkers for colorectal adenoma diagnosis corresponded to $0.75(0.70-0.80), 0.71(0.66-0.77)$, and 0.64 $(0.59-0.70)$ for adiponectin, IGF-1, and TNF- $\alpha$, respectively. However, the AUC was lowest for Leptin. This study should be validated in a large sample size cohort. African-Americans have a higher obesity burden and are at high risk of colorectal adenoma and cancer. In conclusion, we demonstrated that circulating levels of adiponectin, TNF- $\alpha$, and IGF-1 were associated with colorectal adenoma risk and as such might be good biomarkers for colorectal adenoma risk in African Americans.

\section{ETHICS STATEMENT}

The study was approved by the Howard University Institutional Review Board (06-MED-39) and consent forms were obtained from all participants. 


\section{AUTHOR CONTRIBUTIONS}

$\mathrm{HA}, \mathrm{HB}$, and $\mathrm{SN}$ study design and manuscript writing and critical evaluation of data; KS, AN, AL, GN-B, and AS collecting data/ literature review; and SN performed statistical analysis.

\section{REFERENCES}

1. Siegel R, Naishadham D, Jemal A. Cancer statistics, 2012. CA Cancer J Clin (2012) 62:10-29. doi:10.3322/caac.20138

2. Agrawal S, Bhupinderjit A, Bhutani MS, Boardman L, Nguyen C, Romero Y, et al. Colorectal cancer in African Americans. Am J Gastroenterol (2005) 100:515-23; discussion 514. doi:10.1111/j.1572-0241.2005.41829.x

3. Ashktorab H, Vilmenay K, Brim H, Laiyemo AO, Kibreab A, Nouraie M. Colorectal cancer in Young African Americans: is it time to revisit guidelines and prevention? Dig Dis Sci (2016) 61(10):3026-30. doi:10.1007/s10620016-4207-1

4. Bardou M, Barkun AN, Martel M. Obesity and colorectal cancer. Gut (2013) 62:933-47. doi:10.1136/gutjnl-2013-304701

5. Wiseman M. The second World Cancer Research Fund/American Institute for Cancer Research expert report. Food, nutrition, physical activity, and the prevention of cancer: a global perspective. Proc Nutr Soc (2008) 67:253-6. doi:10.1017/S002966510800712X

6. Alberti KG, Zimmet P, Shaw J. Metabolic syndrome - a new world-wide definition. A Consensus Statement from the International Diabetes Federation. Diabet Med (2006) 23:469-80. doi:10.1111/j.1464-5491.2006.01858.x

7. Arpaci F, Yilmaz MI, Ozet A, Ayta H, Ozturk B, Komurcu S, et al. Low serum leptin level in colon cancer patients without significant weight loss. Tumori (2002) 88:147-9.

8. Baratta M. Leptin - from a signal of adiposity to a hormonal mediator in peripheral tissues. Med Sci Monit (2002) 8:RA282-92.

9. Margetic S, Gazzola C, Pegg GG, Hill RA. Leptin: a review of its peripheral actions and interactions. Int J Obes Relat Metab Disord (2002) 26:1407-33. doi:10.1038/sj.ijo.0802142

10. Mora S, Pessin JE. An adipocentric view of signaling and intracellular trafficking. Diabetes Metab Res Rev (2002) 18:345-56. doi:10.1002/dmrr.321

11. Beltowski J. Adiponectin and resistin - new hormones of white adipose tissue. Med Sci Monit (2003) 9:RA55-61.

12. Friedman JM, Halaas JL. Leptin and the regulation of body weight in mammals. Nature (1998) 395:763-70. doi:10.1038/27376

13. Faraj M, Havel PJ, Phelis S, Blank D, Sniderman AD, Cianflone K. Plasma acylation-stimulating protein, adiponectin, leptin, and ghrelin before and after weight loss induced by gastric bypass surgery in morbidly obese subjects. J Clin Endocrinol Metab (2003) 88:1594-602. doi:10.1210/jc.2002-021309

14. Housa D, Housova J, Vernerova Z, Haluzik M. Adipocytokines and cancer. Physiol Res (2006) 55:233-44.

15. Kelesidis I, Kelesidis T, Mantzoros CS. Adiponectin and cancer: a systematic review. Br J Cancer (2006) 94:1221-5. doi:10.1038/sj.bjc.6603051

16. Hursting SD, Lashinger LM, Wheatley KW, Rogers CJ, Colbert LH, Nunez NP, et al. Reducing the weight of cancer: mechanistic targets for breaking the obesity-carcinogenesis link. Best Pract Res Clin Endocrinol Metab (2008) 22: 659-69. doi:10.1016/j.beem.2008.08.009

17. Nishida M, Funahashi T, Shimomura I. Pathophysiological significance of adiponectin. Med Mol Morphol (2007) 40:55-67. doi:10.1007/s00795-007-0366-7

18. Fujisawa T, Endo H, Tomimoto A, Sugiyama M, Takahashi H, Saito S, et al. Adiponectin suppresses colorectal carcinogenesis under the high-fat diet condition. Gut (2008) 57:1531-8. doi:10.1136/gut.2008.159293

19. Sugiyama M, Takahashi $H$, Hosono K, Endo H, Kato S, Yoneda K, et al. Adiponectin inhibits colorectal cancer cell growth through the AMPK/mTOR pathway. Int J Oncol (2009) 34:339-44.

20. Otake S, Takeda H, Suzuki Y, Fukui T, Watanabe S, Ishihama K, et al. Association of visceral fat accumulation and plasma adiponectin with colorectal adenoma: evidence for participation of insulin resistance. Clin Cancer Res (2005) 11:3642-6. doi:10.1158/1078-0432.CCR-04-1868

21. Williams CJ, Mitsiades N, Sozopoulos E, Hsi A, Wolk A, Nifli AP, et al. Adiponectin receptor expression is elevated in colorectal carcinomas but not

\section{FUNDING}

This project was supported (in part) by the National Institute on Minority Health and Health Disparities of the National Institutes of Health under Award Number G12MD007597.

in gastrointestinal stromal tumors. Endocr Relat Cancer (2008) 15:289-99. doi:10.1677/ERC-07-0197

22. Yoneda K, Tomimoto A, Endo H, Iida H, Sugiyama M, Takahashi H, et al. Expression of adiponectin receptors, AdipoR1 and AdipoR2, in normal colon epithelium and colon cancer tissue. Oncol Rep (2008) 20:479-83.

23. Babic A, Bao Y, Qian ZR, Yuan C, Giovannucci EL, Aschard H, et al. Pancreatic cancer risk associated with prediagnostic plasma levels of leptin and leptin receptor genetic polymorphisms. Cancer Res (2016) 76:7160-7. doi:10.1158/ 0008-5472.CAN-16-1699

24. Somasundar P, McFadden DW, Hileman SM, Vona-Davis L. Leptin is a growth factor in cancer. J Surg Res (2004) 116:337-49. doi:10.1016/j.jss.2003.09.004

25. Van Gaal LF, Wauters MA, Mertens IL, Considine RV, De Leeuw IH. Clinical endocrinology of human leptin. Int J Obes Relat Metab Disord (1999) 23 (Suppl 1):29-36. doi:10.1038/sj.ijo.0800792

26. Ho GY, Wang T, Gunter MJ, Strickler HD, Cushman M, Kaplan RC, et al. Adipokines linking obesity with colorectal cancer risk in postmenopausal women. Cancer Res (2012) 72:3029-37. doi:10.1158/0008-5472.CAN-11-2771

27. Hardwick JC, Van Den Brink GR, Offerhaus GJ, Van Deventer SJ, Peppelenbosch MP. Leptin is a growth factor for colonic epithelial cells. Gastroenterology (2001) 121:79-90. doi:10.1053/gast.2001.25490

28. Stattin P, Lukanova A, Biessy C, Soderberg S, Palmqvist R, Kaaks R, et al. Obesity and colon cancer: does leptin provide a link? Int J Cancer (2004) 109:149-52. doi:10.1002/ijc.11668

29. Schedlich LJ, Young TF, Firth SM, Baxter RC. Insulin-like growth factorbinding protein (IGFBP)-3 and IGFBP-5 share a common nuclear transport pathway in T47D human breast carcinoma cells. J Biol Chem (1998) 273:18347-52. doi:10.1074/jbc.273.29.18347

30. Jenkins PJ, Besser GM, Fairclough PD. Colorectal neoplasia in acromegaly. Gut (1999) 44:585-7. doi:10.1136/gut.44.5.585

31. Comstock SS, Hortos K, Kovan B, McCaskey S, Pathak DR, Fenton JI. Adipokines and obesity are associated with colorectal polyps in adult males: a cross-sectional study. PLoS One (2014) 9:e85939. doi:10.1371/journal. pone.0085939

32. Szlosarek PW, Balkwill FR. Tumour necrosis factor alpha: a potential target for the therapy of solid tumours. Lancet Oncol (2003) 4:565-73. doi:10.1016/ S1470-2045(03)01196-3

33. Tisdale MJ. Cancer cachexia. Langenbecks Arch Surg (2004) 389:299-305.

34. Olsen RS, Nijm J, Andersson RE, Dimberg J, Wagsater D. Circulating inflammatory factors associated with worse long-term prognosis in colorectal cancer. World J Gastroenterol (2017) 23:6212-9. doi:10.3748/wjg. v23.i34.6212

35. Godos J, Biondi A, Galvano F, Basile F, Sciacca S, Giovannucci EL, et al. Markers of systemic inflammation and colorectal adenoma risk: meta-analysis of observational studies. World J Gastroenterol (2017) 23:1909-19. doi:10.3748/ wjg.v23.i10.1909

36. Name N, Boonpipattanapong T, Palanusont A, Maneechay W, Sangkhathat S. Alteration of leptin and adiponectin in multistep colorectal tumorigenesis. Asian Pac J Cancer Prev (2016) 17.

37. Kumor A, Daniel P, Pietruczuk M, Malecka-Panas E. Serum leptin, adiponec tin, and resistin concentration in colorectal adenoma and carcinoma (CC) patients. Int J Colorectal Dis (2009) 24:275-81. doi:10.1007/s00384-008-0605-y

38. Gao Y, Katki H, Graubard B, Pollak M, Martin M, Tao Y, et al. Serum IGF-1, IGF2 and IGFBP3 and risk of advanced colorectal adenoma. Int J Cancer (2012) 131:E105-13. doi:10.1002/ijc.26438

39. Kang HW, Kim D, Kim HJ, Kim CH, Kim YS, Park MJ, et al. Visceral obesity and insulin resistance as risk factors for colorectal adenoma: a cross-sectional, case-control study. Am J Gastroenterol (2010) 105:178-87. doi:10.1038/ajg. 2009.541

40. Chung YW, Han DS, Park YK, Son BK, Paik CH, Lee HL, et al. Association of obesity, serum glucose and lipids with the risk of advanced colorectal adenoma 
and cancer: a case-control study in Korea. Dig Liver Dis (2006) 38:668-72. doi:10.1016/j.dld.2006.05.014

41. Palmer LJ, Buxbaum SG, Larkin EK, Patel SR, Elston RC, Tishler PV, et al. Whole genome scan for obstructive sleep apnea and obesity in AfricanAmerican families. Am J Respir Crit Care Med (2004) 169:1314-21. doi:10.1164/rccm.200304-493OC

42. Keimling M, Renehan AG, Behrens G, Fischer B, Hollenbeck AR, Cross AJ, et al. Comparison of associations of body mass index, abdominal adiposity, and risk of colorectal cancer in a large prospective cohort study. Cancer Epidemiol Biomarkers Prev (2013) 22:1383-94. doi:10.1158/1055-9965. EPI-13-0353

43. Martinez ME, Giovannucci E, Spiegelman D, Hunter DJ, Willett WC, Colditz GA. Leisure-time physical activity, body size, and colon cancer in women. Nurses' Health Study Research Group. J Natl Cancer Inst (1997) 89:948-55. doi:10.1093/ jnci/89.13.948

44. Wei EK, Giovannucci E, Fuchs CS, Willett WC, Mantzoros CS. Low plasma adiponectin levels and risk of colorectal cancer in men: a prospective study. J Natl Cancer Inst (2005) 97:1688-94. doi:10.1093/jnci/dji376

45. Nakajima TE, Yamada Y, Hamano T, Furuta K, Matsuda T, Fujita S, et al. Adipocytokines as new promising markers of colorectal tumors: adiponectin for colorectal adenoma, and resistin and visfatin for colorectal cancer. Cancer Sci (2010) 101:1286-91. doi:10.1111/j.1349-7006.2010. 01518.x

46. Yamaji T, Iwasaki M, Sasazuki S, Tsugane S. Interaction between adiponectin and leptin influences the risk of colorectal adenoma. Cancer Res (2010) 70:5430-7. doi:10.1158/0008-5472.CAN-10-0178

47. Fukumoto J, Otake T, Tajima O, Tabata S, Abe H, Mizoue T, et al. Adiponectin and colorectal adenomas: self Defense Forces Health Study. Cancer Sci (2008) 99:781-6. doi:10.1111/j.1349-7006.2008.00745.x

48. Lukanova A, Soderberg S, Kaaks R, Jellum E, Stattin P. Serum adiponectin is not associated with risk of colorectal cancer. Cancer Epidemiol Biomarkers Prev (2006) 15:401-2. doi:10.1158/1055-9965.EPI-05-0836

49. Stocks T, Lukanova A, Johansson M, Rinaldi S, Palmqvist R, Hallmans G, et al. Components of the metabolic syndrome and colorectal cancer risk; a prospective study. Int J Obes (Lond) (2008) 32:304-14. doi:10.1038/sj.ijo. 0803713

50. Ferroni P, Palmirotta R, Spila A, Martini F, Raparelli V, Fossile E, et al. Prognostic significance of adiponectin levels in non-metastatic colorectal cancer. Anticancer Res (2007) 27:483-9.

51. Chong DQ, Mehta RS, Song M, Kedrin D, Meyerhardt JA, Ng K, et al. Prediagnostic plasma adiponectin and survival among patients with colorectal cancer. Cancer Prev Res (Phila) (2015) 8:1138-45. doi:10.1158/1940-6207. CAPR-15-0175

52. Inamura $\mathrm{K}$, Song $\mathrm{M}$, Jung $\mathrm{S}$, Nishihara $\mathrm{R}$, Yamauchi $\mathrm{M}$, Lochhead $\mathrm{P}$, et al. Prediagnosis plasma adiponectin in relation to colorectal cancer risk according to KRAS mutation status. J Natl Cancer Inst (2016) 108:1-10.

53. Gunter MJ, Leitzmann MF. Obesity and colorectal cancer: epidemiology, mechanisms and candidate genes. J Nutr Biochem (2006) 17:145-56. doi:10.1016/j. jnutbio.2005.06.011

54. Fantuzzi G. Adipose tissue, adipokines, and inflammation. J Allergy Clin Immunol (2005) 115:911-9. doi:10.1016/j.jaci.2005.02.023 quiz 920,

55. Wang Y, Lam KS, Xu JY, Lu G, Xu LY, Cooper GJ, et al. Adiponectin inhibits cell proliferation by interacting with several growth factors in an oligomerization-dependent manner. J Biol Chem (2005) 280:18341-7. doi:10.1074/jbc.M501149200

56. Rouet-Benzineb P, Aparicio T, Guilmeau S, Pouzet C, Descatoire V, Buyse M, et al. Leptin counteracts sodium butyrate-induced apoptosis in human colon cancer HT-29 cells via NF-kappaB signaling. J Biol Chem (2004) 279: 16495-502. doi:10.1074/jbc.M312999200

57. Tartaglia LA. The leptin receptor. J Biol Chem (1997) 272:6093-6. doi:10.1074/ jbc. 272.10 .6093
58. Barr VA, Lane K, Taylor SI. Subcellular localization and internalization of the four human leptin receptor isoforms. J Biol Chem (1999) 274:21416-24. doi:10.1074/jbc.274.30.21416

59. Stattin P, Palmqvist R, Soderberg S, Biessy C, Ardnor B, Hallmans G, et al. Plasma leptin and colorectal cancer risk: a prospective study in Northern Sweden. Oncol Rep (2003) 10:2015-21.

60. Uchiyama T, Takahashi H, Sugiyama M, Sakai E, Endo H, Hosono K, et al. Leptin receptor is involved in STAT3 activation in human colorectal adenoma. Cancer Sci (2011) 102:367-72. doi:10.1111/j.1349-7006.2010.01803.x

61. Tessitore L, Vizio B, Jenkins O, De Stefano I, Ritossa C, Argiles JM, et al. Leptin expression in colorectal and breast cancer patients. Int J Mol Med (2000) 5:421-6.

62. Yoon YS, Keum N, Zhang X, Cho E, Giovannucci EL. Circulating levels of IGF-1, IGFBP-3, and IGF-1/IGFBP-3 molar ratio and colorectal adenomas: a meta-analysis. Cancer Epidemiol (2015) 39:1026-35. doi:10.1016/j.canep. 2015.09.004

63. Ochs-Balcom HM, Vaughn CB, Nie J, Chen Z, Thompson CL, Parekh N, et al. Racial differences in the association of insulin-like growth factor pathway and colorectal adenoma risk. Cancer Causes Control (2014) 25:161-70. doi:10.1007/s10552-013-0318-6

64. Yamaji T, Iwasaki M, Sasazuki S, Tsugane S. Gender difference in the association of insulin and the insulin-like growth factor axis with colorectal neoplasia. Int J Obes (Lond) (2012) 36:440-7. doi:10.1038/ijo.2011.114

65. Il'yasova D, Colbert LH, Harris TB, Newman AB, Bauer DC, Satterfield S, et al. Circulating levels of inflammatory markers and cancer risk in the health aging and body composition cohort. Cancer Epidemiol Biomarkers Prev (2005) 14:2413-8. doi:10.1158/1055-9965.EPI-05-0316

66. Kang M, Peery AF, Locklear C, Galanko JA, Sandler RS, Keku TO. Plasma insulin, glucose, IGF-I, IGF-II, and IGFBP-3 and risk of recurrent colorectal adenomas. J Gastroenterol Hepatol Res (2013) 2:531-5.

67. Jacobs ET, Martinez ME, Alberts DS, Ashbeck EL, Gapstur SM, Lance P, et al. Plasma insulin-like growth factor I is inversely associated with colorectal adenoma recurrence: a novel hypothesis. Cancer Epidemiol Biomarkers Prev (2008) 17:300-5. doi:10.1158/1055-9965.EPI-07-0764

68. Kim S, Keku TO, Martin C, Galanko J, Woosley JT, Schroeder JC, et al. Circulating levels of inflammatory cytokines and risk of colorectal adenomas. Cancer Res (2008) 68:323-8. doi:10.1158/0008-5472.CAN-07-2924

69. Vaughn CB, Ochs-Balcom HM, Nie J, Chen Z, Thompson CL, Tracy R, et al. No association between circulating levels and genetic variants of IL- 6 and TNF- $\alpha$ and colon adenoma. Gastroenterol Res (2013) 6:43-8.

70. Nikiteas NI, Tzanakis N, Gazouli M, Rallis G, Daniilidis K, Theodoropoulos G, et al. Serum IL-6, TNFalpha and CRP levels in Greek colorectal cancer patients: prognostic implications. World J Gastroenterol (2005) 11:1639-43. doi:10.3748/ wjg.v11.i11.1639

71. Ryan AS, Berman DM, Nicklas BJ, Sinha M, Gingerich RL, Meneilly GS, et al. Plasma adiponectin and leptin levels, body composition, and glucose utilization in adult women with wide ranges of age and obesity. Diabetes Care (2003) 26:2383-8. doi:10.2337/diacare.26.8.2383

Conflict of Interest Statement: The authors declare that the research was conducted in the absence of any commercial or financial relationships that could be construed as a potential conflict of interest.

The reviewer GM and handling Editor declared their shared affiliation.

Copyright (๑) 2018 Ashktorab, Soleimani, Nichols, Sodhi, Laiyemo, Nunlee-Bland, Nouraie and Brim. This is an open-access article distributed under the terms of the Creative Commons Attribution License (CC BY). The use, distribution or reproduction in other forums is permitted, provided the original author(s) and the copyright owner are credited and that the original publication in this journal is cited, in accordance with accepted academic practice. No use, distribution or reproduction is permitted which does not comply with these terms. 